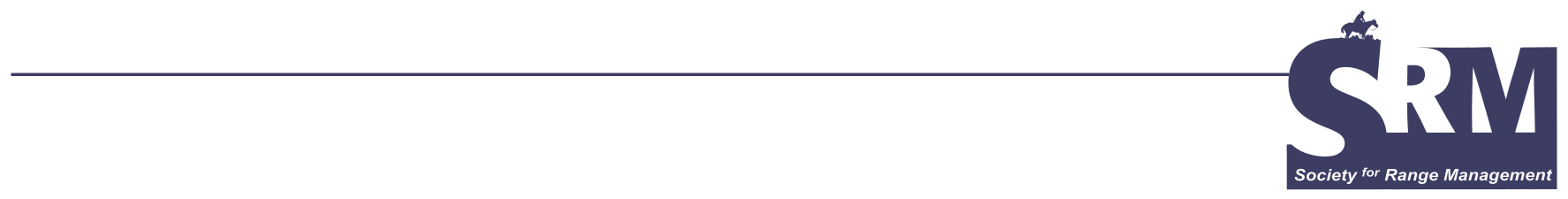

\title{
The Local Livestock Sale Barn
}

\section{By Gary Frasier, Roger Herrick, and Jackie Herrick}

\section{Remembering the Past}

One of the things remembered from growing up on ranches in Southwestern Nebraska was the local sale barn. Many of the towns had a sale barn where local farmers and ranchers could bring their livestock for sale or where they could buy animals they wanted. Sale day in these towns was the busiest day of the week. People would go to town to do their weekly purchasing and to see their neighbors to catch up on the gossip. If the sale day was on Saturday, the kids would frequently go to the afternoon matinee at the local movie theater.

Most sale barns consisted of a group of pens where the animals could be held prior to and after the actual sale. Frequently the animals were sorted into small groups with like features (such as weight or conformation). The actual sale was held in an enclosed ring that could hold 10 to 20

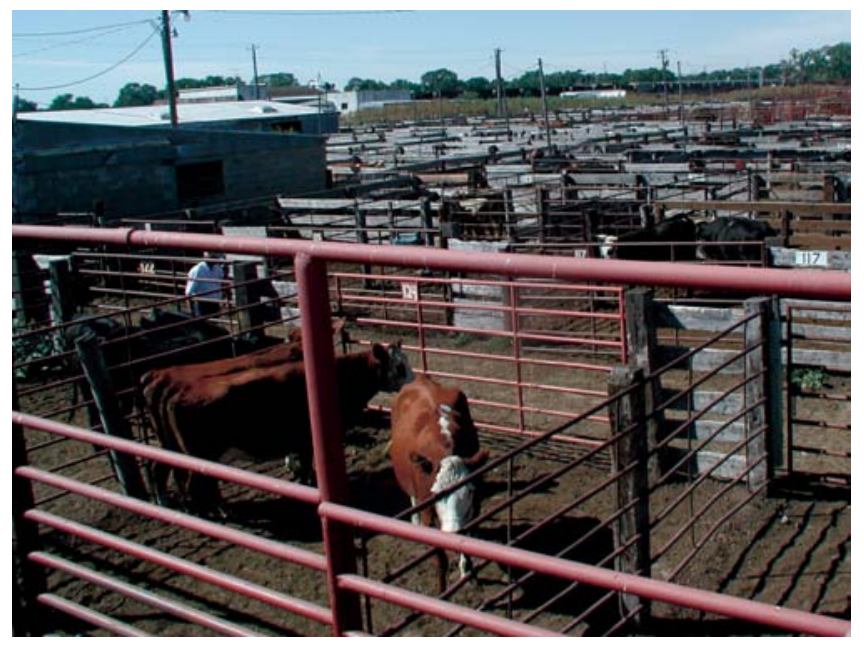

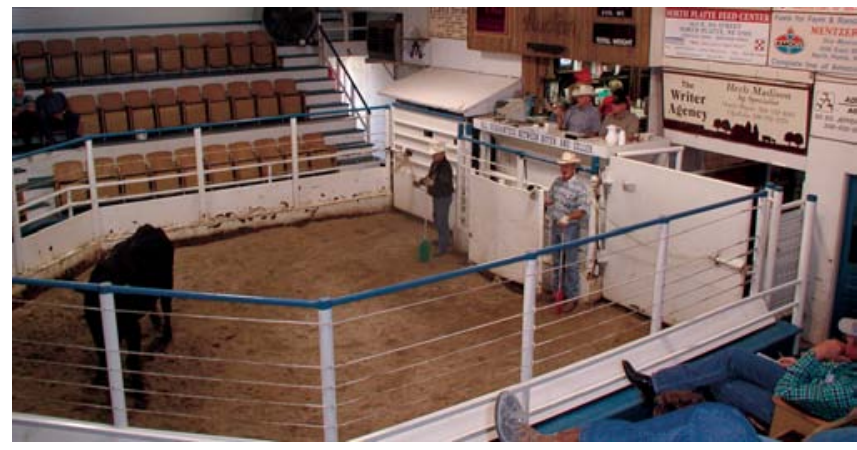

animals at a time. The sale ring was surrounded by tiered seats where the buyers and sellers could sit. The auctioneer was seated on the other side of the ring on a raised podium where he could see the group. Usually there was a scale for weighing the animals behind the auctioneer. Most animals were sold before weighing. This put a lot of pressure on the buyer to judge the weights of the animals when observing them in the ring.

As a small child (Frasier) sitting with my father and grandfather in the tiered seats around the sale ring, listening to the auctioneer do his chant was fascinating. To the uninitiated, the auctioneer's sales pitch is a bunch of disconnected repeated words. This is not true. The auctioneer uses a series of words in a "sing-song" chant to repeat the price they are looking for. They usually start at a low value and increase the asking price as the various bidders signal their acceptance. Many of the buyers would only nod their head or move a finger to note that they were accepting the price being offered. There were 2-3 "ring people" who would be moving the animals around for viewing. They also had the task of finding 


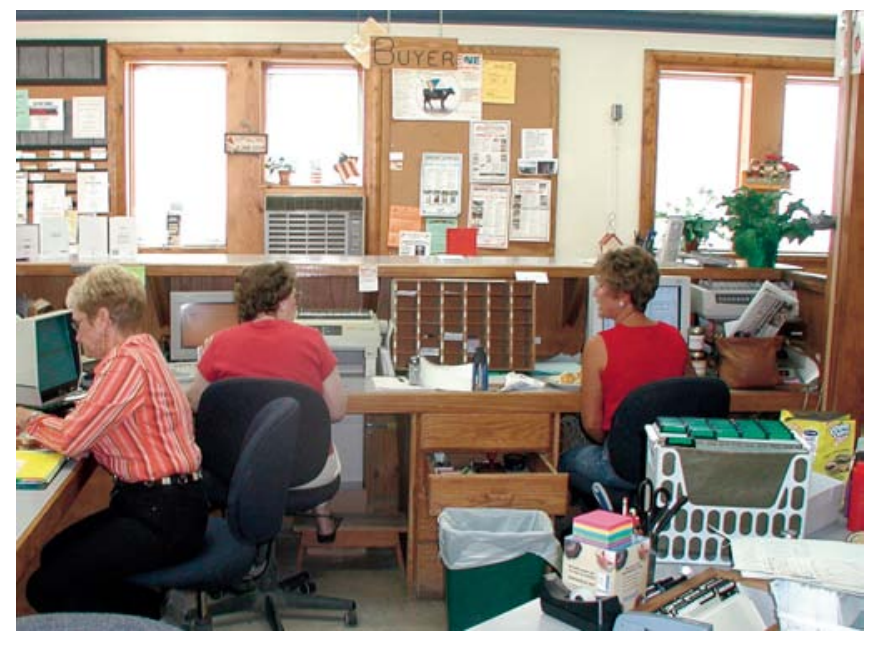

the buyers and "yelling out" when a bid was accepted. Once a bid was accepted the auctioneer would increase the asking price. When the asking price reached a point that drew no more bidders, the auctioneer would announce the animals as sold. It was a real challenge to a small child to look around and try to identify who was bidding on the animals.

For a seller, sale day would start several days in advance of the actual sale. The livestock would be rounded from the pastures and sorted as to what animals would be sold. If the rancher had a large number of animals to be sold, they were frequently hauled to town in large semi trucks ("pots") which could double-deck smaller animals. Smaller groups of livestock would be hauled in the rancher's farm truck. As a youngster this was an exciting time, watching the cattle being driven up the loading chute into the waiting trucks. After the animals were loaded we would clean up and drive to town.

Most sales would start about noon. This allowed time for the farmers and ranchers to get the animals to the sale barn. As the animals were brought in they were inspected by the State Brand Inspector assigned to the area to ensure ownership. The animals would be put into a small pen until time for their turn to be sold. Frequently, prospective cattle buyers would make a round of the holding pens to see what was available and to make a judgment as to how much they thought the animals would sell for.

In some instances, if the livestock was being hauled in from some distance, the animals would be brought in a day or two in advance to allow for feeding and watering before being auctioned off. This was an added expense but the animals would look better and maybe weigh a little more by replacing the "shrink" water lost during moving. In the fall of the year when the yearling calves were brought in from the grass rangelands, the sales might last until the wee hours of the next morning.

Sale day would end by going into the sale barn business office and receiving a check for the animals sold, or paying for the animals purchased. If animals were bought, arrangements were made to have a trucker haul them home, marking the end of a long day for a small child....

\section{Weigh-ups}

Weigh-ups are cows, bulls, and other odd lot animals that are being culled out of the herd. They might be old cows that the calves have been weaned off of and aren't productive anymore. Some weigh-ups are old bulls, or sometimes a young bull that has gotten hurt or crippled and can't be used for breeding anymore. They are sold by the pound and usually are made into hamburger. Some buyers come in only for the weigh-up part of the sale and are usually buying for some packing plant.

Some sales have up to 500 weigh-ups. When prices are extremely high, the producers will dump older animals like crazy. Some old cows will "pound" out (sell by the pound) to about as much as a bred cow would bring. Some of the big bulls bring prices in the 70 to 80 cents-per-pound range as weigh-ups, which is a lot of money for a 2,000-pound bull. In some years, a lot of stock that is still capable of being in the herd may be culled just because the weigh-up market is high.

Each sale barn would have a small restaurant where you could get anything from a cup of coffee to a complete meal. Usually they had pies for sale also. The restaurant was a good place to visit with your neighbor. The sale barn in my local town had a waitress that was the most efficient and pleasant person you would ever want to meet. She knew everyone in the county and never had a bad word to say about anyone. When I saw her last, she said she was still working. She has to be pushing 50 years of working there. She has some of the best stories to tell about the people. One of the favorite stories is this:

One day a local man came in and said, "I'm ready to marry you." She replied, "I'm already happily married. My husband is out there working the ring." He said, "Well I was talking to your husband and he said that you were a good wife, but that you had had a squabble with him this morning and he wasn't sure if you would be back." She replied, "I have been married to that man for over 40 years and plan to be married for a long time to come. I am sure not going to try to break a new one in."

In many areas the local sale barn has gone the way of the buffalo. There are still sale barns around in some of the larger towns of the west. They still operate in much the same

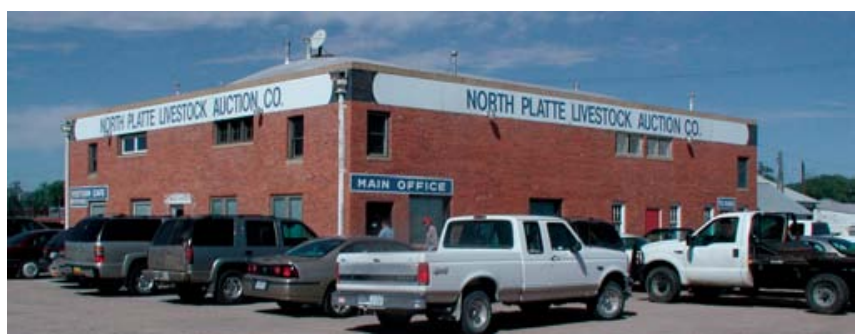




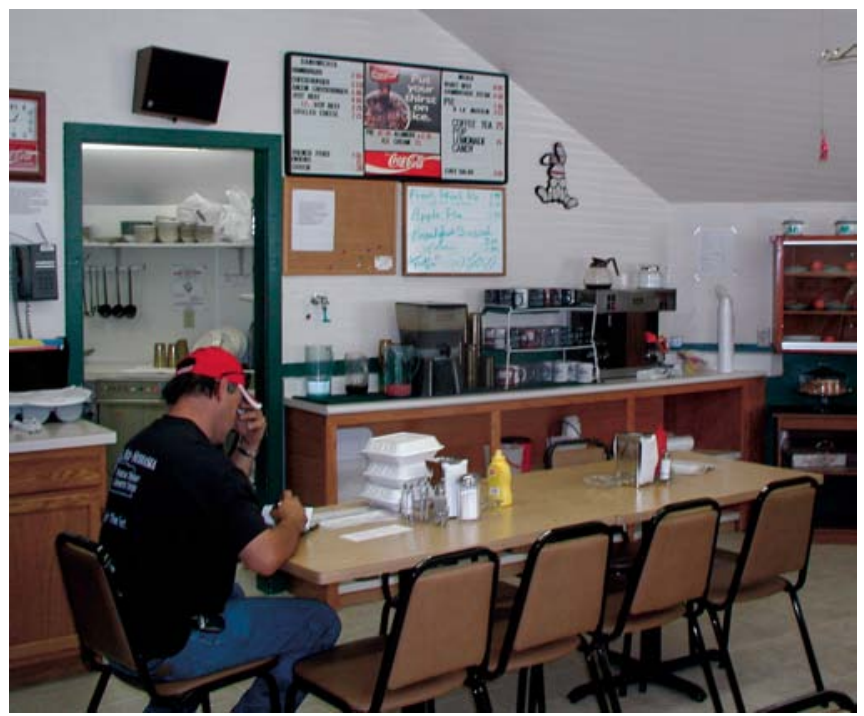

way of selling animals. What is gone is the "event" they used to create in going to town and seeing relatives and neighbors and just having a good time.

\section{A Sale Barn of Today}

My name is Jackie Herrick. My husband, Roger, and I have owned and operated the North Platte Livestock Auction for the past 13 years. Gary Frasier has asked that we write about our experience with the sale barn life.

First I would like to say that Gary and I are cousins. Our dads were brothers and our mothers were sisters. We were both raised on cattle ranches in the Dundy County area of Nebraska. So our childhoods were similar in regard to the ranching life. Roger has been around sale barns all his life. His dad was a brand inspector and Roger helped around the barns in Benkelman, Nebraska, from his 5th grade on. $\mathrm{He}$ has been involved in the cattle industry all his adult life. Our purpose as owners of a livestock sale barn is to get the highest market value for the seller and the best condition and purchase price for the buyer so that both will be satisfied customers. Sometimes that can be a challenge. We have lived through blizzards before big sales, mad-cow disease scares, and the Black Monday stock market scare; even 9/11 was on a "big sale" day.

There is an excitement that is felt on a large cattle sale day. Buyers represent many states on sale days. The buyers try to get there early enough to have a good dinner at the cafe and then get settled in for the long afternoon. The first animals sold are the weigh-ups. The buyers that start coming in around noon are the ones that come for the quality cattle that are selling in the big bunches. Some are order buyers for someone else and some are the producers, who are interested in buying for themselves.

\section{Video Auctions}

Auction Markets as we know them now are in for a big change. Some of the barns have gone to the video sales in addition to regular sales. At some video sales the buyers sit at tables, have a big prime rib meal, and bid on the cattle that have been videotaped on the ranch. Buyers can also be at home and watch it either on a certain TV station or on the Internet. This is all live, so all can bid.

The auctioneer and ring men can be heard in the adjacent business sale office as each group of cattle is sold and bids are taken. A lot of "yipping" from the ring men means the sale is going well!!

Hours go into planning each sale. Advertisement goes out 6 days before the sale. Buyers have to be called each week to let them know what is coming for the sale. Many producers want the barn owner to look at the cattle before they consign them.

Most cattle have to be sorted to sex, weight, and color. In today's sale barns the ring is the scale, so the buyer knows the weight before he bids.

I can see changes coming in the future. Cattle are sold by using videos of the stock. They are shown on big screens at large gatherings and also on TV. You can bid by phone on these cattle or you can attend the sale. You can also watch an actual sale barn auction on the Internet and bid with your computer as the cattle are in the sale-barn ring.

A lot of the smaller producers won't have as many options to sell their cattle if the sale barns as we know them start disappearing. The video buyer likes load lots. Auction markets are essential for giving the smaller producer a competitive selling tool.

If the trend to video sales continues, it will be hard for the livestock auction markets that just try to sell cattle at the barn to survive. The overhead of an auction barn is extremely high and the rules and regulations that have to be followed can sometimes be overwhelming. I can't see that sale barns will survive as they are now by just selling weigh-ups and the cutoffs that can't make it on the videos.

Many livestock producers still see the sale-barn auction market as the true test for the actual market. We get many calls a week from producers wanting to know what the true market really is.

It really is up to the producers if the traditional auction market is going to survive.

Authors are Editor-in-Chief of Rangelands (Gary Frasier) and Owners of the North Platte Livestock Auction in North Platte, $N E$ (Roger and Jackie Herrick). 